\title{
Analisis komoditas unggulan sektor perikanan kelautan dalam menunjang perekonomia masyarakat di Kota Ternate
}

\author{
(Analysis of marine fisheries sector leading commodities in support \\ economic community in Ternate City) \\ Said Assagaf ${ }^{* 1}$, Burhan Abdurahman ${ }^{1}$ dan M. Janib Achmad ${ }^{2}$ \\ ${ }^{1}$ Program Studi Ilmu Ekonomi Pasca Sarjana Universitas KhairunTernate \\ ${ }^{2}$ Fakultas Perikanan dan Kelautan Universitas KhairunTernate \\ Email: ahmadsgff@gmail.com
}

Diterima: 4 Juni 2020; Disetujui: 2 November 2020

\begin{abstract}
ABSTRAK
Analisis komoditas unggulan di suatu daerah merupakan langkah awal menuju pembangunan dan pengelolaan perikanan yang berpijak pada konsep efisiensi untuk meraih keunggulan komparatif dan kompetitif dalam menghadapi globalisasi perdagangan. Penelitian komoditas unggulan merupakan langkah menuju efisiensi, dengan menentukan komoditas perikanan yang mempunyai keunggulan komparatif, baik ditinjau dari sisi penawaran maupun permintaan, serta keunggulan daya saing tinggi. Kota Ternate yang memiliki kondisi geografis dengan perairan yang luas menjadikan daerah ini memiliki kekayaan laut yang sangat potensial untuk dikembangkan. Kegiatan perikanan di Kota Ternate terdiri dari perikanan tangkap, perikanan budidaya dan pengolahan hasil perikanan.Tujuan penelitian ini adalah mengetahui potensi komoditas unggulan sektor perikanan di Kota Ternate. Metode dalam penelitian adalah survey, wawancaradan penelusuran studi pustaka (menggali sumber-sumber sekunder). Hasil penelitian menunjukan bahwa, berdasarkan data PDRB harga konstan kota Ternate, pertanian dan perikanan lebih tinggi menyerap tanaga kerja disbanding sektor lainnya, hasil analisis LQ menunjukan bahwa pertanian perikanan berada pada posisi pertama dengan nilai 0,16 pada tahun 2016 dan 0,16 pada tahun 2017. Untuk istimasi potensi perikanan di perairan kota Ternate memiliki SDI sebesar 6.300,496 ton/tahun, dengan jumlah tangkapan yang diperbolehkan sebesar 5.040,396 ton/tahun.
\end{abstract}

Kata kunci: Unggulan, komoditas, Sektor, Perikanan 


\begin{abstract}
Analysis of superior commodities in a region is the first step towards fisheries development and management based on the concept of efficiency to gain comparative and competitive advantages in the face of trade globalization. Research on superior commodities is a step towards efficiency, by determining fishery commodities that have comparative advantages, both in terms of supply and demand, as well as high competitive advantages. Ternate City which has geographic conditions with wide waters makes this area has a very potential marine wealth to be developed. Fishery activities in Ternate City consist of capture fisheries, aquaculture and fishery product processing. The purpose of this study was to determine the potential of superior commodities in the fisheries sector in Ternate City. The method in this research is survey, interview and literature search (exploring secondary sources). The results showed that, based on GDP constant price data for the city of Ternate, agriculture and fisheries absorbed more labor than other sectors, the results of $L Q$ analysis showed that fisheries agriculture was in the first position with a value of 0.16 in 2016 and 0.16 in 2016. 2017. To estimate the potential of fisheries in the waters of the city of Ternate, it has an SDI of 6,300,496 tons / year, with the amount of catch allowed is 5,040,396 tons / year.
\end{abstract}

Keyword: Superior, Commodity, Sector, Fisheries, Ternate

\title{
I. Pendahuluan
}

Salah satu konsep perencanaan pengembangan wilayah yang cukup populer pada beberapa dekade di negara-negara berkembang seperti Indonesia, adalah konsep pengembangan agropolitan dan minapolitan yang jika digabung menjadi agrominapolitan. Oleh karenanya, implementasi yang bertahap namun berkelanjutan adalah kunci keberhasilan dalam pengembangan potensi unggulan daerah. Perencanaan pengembangan wilayah melalui pendekatan top-down policy, yaitu sejalan dengan arah kebijakan pembangunan perikanan nasional dan bottom-up planing, sesuai dengan kebutuhan masyarakat (petani dan nelayan) di daerah. Analisis komoditas unggulan di suatu daerah merupakan langkah awal menuju pembangunan dan pengelolaan perikanan yang berpijak pada konsep efisiensi untuk meraih keunggulan komparatif dan kompetitif dalam menghadapi globalisasi perdagangan (Irnawatiet al., 2010; Adinugroho. 2016). Langkah menuju efisiensi dapat ditempuh dengan menentukan komoditas perikanan yang mempunyai keunggulan komparatif, baik ditinjau dari sisi penawaran maupun permintaan, serta keunggulan daya saing tinggi (Cikitha, 2018; Irnawati et al., 2010). Dari sisi penawaran, komoditas ikan unggulan dicirikan oleh superioritas dalam pertumbuhan pada kondisi biofisik, teknologi, dan sosial ekonomi nelayan yang dapat dijadikan andalan untuk mendapatkan pendapatan (Irnawati at al., 2011; Adinugroho. 2016). 
Kota Ternate yang memiliki luas $5.709,58 \mathrm{~km}^{2}$ yang terdiri dari daratan seluas $162,03 \mathrm{~km} 2$ dan lautannya 5.547,55 km2,kondisi geografis dengan perairan yang luas menjadikan Ternate memiliki kekayaan laut yang sangat potensial untuk dikembangkan. Kegiatan perikanan Kota Ternate terdiri dari perikanan tangkap, perikanan budidaya dan pengolahan hasil perikanan. Sub Sektor ini merupakan sektor yang yang mendukung perekonomian masyarakat karena kontribusinya dalam penyediaan pangan komoditi laut seperti jenis ikan, udang dan kerangkerangan sangat menjanjikan.Sektor perikanan dan pertanian di kota Ternate melibatkan sekitar 6.408 jiwa penduduk atau sekitar 7,1 \% dari jumlah penduduk usia kerja (usia > 15 tahun)(Ananimous, 2019).

Meskipun sektor perikanan dan pertanian hanya berada di urutan ke lima dari sembilan jenis pekerjaan yang menyumbang tenaga kerja terbanyak, namun hasil produksi dari kedua sektor ini masih menjadi salah satu kategori yang berperan dalam perekonomian Kota Ternate. Kontribusi sektor ini terhadap PDRB tahun 2017 sebesar 339.769,98 atau $4 \%$ dari PDRB Kota Ternate (BPS Kota Ternate, 2018). Permasalahan yang muncul dalam pengembangan sektor perikanan adalah terbatasnya data potensi perikanan, rendahnya sumber daya manusia, minimnya sarana dan prasarana perikanan. Minimnya daya dukung tersebut berakibat pada lemahnya peran kawasan terhadap pengembangan wilayah serta lemahnya peran sentra-sentra industri perikanan.

Penelitian ini penting dilakukan untuk mengidentifikasi kondisi eksisting dan peran sub sektor perikanan terhadap PDRB Kota Ternate per tahun. Hal tersebut menjadi dasar penilaian apakah sub sektor perikanan mempunyai prospek sebagai trigger pengembangan ekonomi wilayah (Mira, 2013; Syarief et al., 2014; Rinanti, 2013; Ariani et al., 2014;Winata et al., 2015). Dampaknya di tingkat wilayah yaitu berupa kontribusi terhadap PDRB (Hamidi et al., 2011; Rizal, 2013; Rostar et al., 2015; Tatali et al., 2013). Tujuan penelitian ini adalah mengetahui peta potensi komoditas unggulan sektor perikanan Kota Ternate. Hal tersebut juga dapat dimanfaatkan untuk meningkatkan perkembangan ekonomi di bagian selatan.

\section{Metodologi Penelitian}

\subsection{Waktu dan Tempat}

Penelitian ini dilaksanakan, pada bulan Mei-September 2019 di 7 kecamatan di Kota Ternate.

\subsection{Pengumpulan Data}

Metode yang digunakan dalam penelitian adalah survey, wawancara. dan penelusuran studi pustaka (menggali sumber-sumber sekunder). Jenis data yang digunakan adalah data primer dan data sekunder. Data primer terdiri dari jenis dan harga ikan hasil tangkapan, pemasaran ikan hasil tangkapan, produksi ikan, jenis dan jumlah alat tangkap, biaya operasi (biaya tetap dan biaya variabel), biaya investasi dan tingkat suku bunga. Data primer diperoleh melalui wawancara dan 
pengamatan. Data sekunder diperoleh melalui studi pustaka, yaitu data time series perikanan tangkap, perikanan budidaya dan pengolahan perikanan.

\subsection{Analisis Data dan Komoditas Ikan Unggulan}

\subsubsection{Analisis Potensi Wilayah}

Analisis potensi wilayah dilakukan untuk mengkaji secara ilmiah rincian semua kekayaan atau sumber daya fisik maupun non fisik pada area atau wilayah Kota Ternate sehingga dapat dikembangkan lebih lanjut menjadi kekuatn tertentu. Hasil dan Pembahasan sebagai kriteria. Dengan analisis ini akan diketahui apakah suatu lokasi/wilayah merupakan wilayah basis atau non basis dari salah satu produk unggulan. Analisis LQ dirumuskan sebagai berikut:

$$
\begin{aligned}
& \mathrm{LQ}=\mathrm{Si} / \mathrm{Ni} \\
& \mathrm{Si}=\mathrm{pi} / \mathrm{pt} \\
& \mathrm{Ni}=\mathrm{Pi} / \mathrm{Pt}, \\
& \text { Sehingga } \mathrm{LQ}=(\mathrm{pi} / \mathrm{pt}) /(\mathrm{Pi} / \mathrm{Pt})
\end{aligned}
$$

\section{Keterangan:}

pi = luas areal panen komoditas i pada tingkat kecamatan; atau jumlahpopulasi/produksi komoditas i pada tingat kecamatan

pt $=$ total luas areal panen subsektor pada tingkat kecamatanatau jumlah total populasi/produksi subsektor pada tingat kecamatan

$\mathrm{Pi}=$ luas areal panen komoditas i pada tingkat Kabupaten Atau jumlah panen/produksipopulasi komoditas i pada tingat kabupaten

$\mathrm{Pt}=$ total luas areal panen subsektor pada tingkat Kabupatenatau total panen/produksi/populasi subsektor pada tingkat kabupaten.

Kriteria penentuan keputusan:

Jika LQ>1 : komoditas itu menjadi basis atau menjadi sumber pertubuhan, komoditas memiliki keunggulan komparatif, hasilnya tidak saja memenuhi kebutuhan di wilayah, tapi juga dapat diekspor ke luar wilayah;

LQ =1 : komoditas tergolog non basis, tidak memiliki keunggulan komparatif. Produksinya hanya cukup untuk memenuhi kebutuhan wilayah sendiri dan tidak mampu untuk diekspor

LQ $<1 \quad$ : komoditas ini jug atermasuk non basis. Produksi komoditas di suatu wilayah tidak dapat memenuhi kebutuhan senidir sehingga perlu dipasok dari luar daerah.

\section{Hasil dan Pembahasan}

3.1.Analisis Potensi Ekonomi dan SektorUnggulan 
Sektor perikanan sebagai salah satu kontributor PDRB Kota Ternate,besarnya pertumbuhan sektor ini berada di bawah laju pertumbuhan wilayah Kota Ternate secara umum. Dalam PDRB harga konstan, pertumbuhan sektor pertanian dan perikanan hanya sebesar 3,077 sedangkan pertumbuhan wilayah adalah 7,79. Sektor Pertanian dan perikanan hanya berkontribusi sebesar 3,53\%. Dengan target pertumbuhan tersebut maka tren PDRB sampai tahun 2020 akan sama dengan 11.799.298,38. Proyeksi PDRB atas Dasar Harga Konstan 20132020 (Tabel 3.1).

Tabel1. Produk Domestik Regional Bruto Atas Dasar Harga Konstan 2010 Menurut Lapangan Usaha di Kota Ternate (juta rupiah), 2015-2017 dan proyeksi 2018-2020

\begin{tabular}{|c|c|c|c|c|c|c|}
\hline \multirow[b]{2}{*}{ Sektor } & \multicolumn{6}{|c|}{ Tahun } \\
\hline & 2015 & 2016 & 2017 & $\begin{array}{c}\text { Proyeksi } \\
2018\end{array}$ & Proyeksi 2019 & Proyeksi 2020 \\
\hline $\begin{array}{l}\text { Pertanian dan } \\
\text { perikanan }\end{array}$ & $294.673,84$ & $316.733,54$ & $339.769,98$ & $364.843,77$ & $391.573,61$ & $420.366,06$ \\
\hline $\begin{array}{l}\text { Pertambangan } \\
\text { dan Penggalian }\end{array}$ & $4.873,00$ & $5.375,08$ & $6.175,08$ & $6.952,73$ & $7.907,93$ & $8.949,08$ \\
\hline $\begin{array}{l}\text { Industri } \\
\text { Pengolahan }\end{array}$ & $251.835,64$ & $277.049,21$ & $287.269,54$ & $306.948,81$ & $323.124,17$ & $342.705,78$ \\
\hline $\begin{array}{l}\text { Pengadaan } \\
\text { listrik dan gas }\end{array}$ & $7.899,78$ & $11.132,13$ & $13.161,89$ & $17.054,54$ & $21.131,30$ & $26.781,75$ \\
\hline $\begin{array}{l}\text { Pengadaan Air, } \\
\text { Pengelolaan } \\
\text { Sampah, } \\
\text { Limbah dan } \\
\text { Daur Ulang }\end{array}$ & $5.436,87$ & $5.976,82$ & $6.504,16$ & $7.114,07$ & $7.761,46$ & $8.478,51$ \\
\hline Konstruksi & $478.961,50$ & $515.234,49$ & $576.154,17$ & $632.032,30$ & $700.045,77$ & $771.658,86$ \\
\hline $\begin{array}{l}\text { Perdagangan } \\
\text { Besar dan Kecil }\end{array}$ & $1.798 .739,59$ & $2.038 .861,37$ & $2.235 .634,07$ & $2.492 .738,18$ & $2.756 .362,50$ & $3.060 .609,36$ \\
\hline $\begin{array}{l}\text { Transportasi dan } \\
\text { Pergudangan }\end{array}$ & $1.153 .944,00$ & $1.284 .317,53$ & $1.466 .397,26$ & $1.653 .181,37$ & $1.875 .656,42$ & $2.121 .320,60$ \\
\hline $\begin{array}{l}\text { Penyediaan } \\
\text { akomodasi dan } \\
\text { Makan }\end{array}$ & $76.505,24$ & $87.855,84$ & $98.406,57$ & $111.615,44$ & $125.808,40$ & $142.250,74$ \\
\hline $\begin{array}{l}\text { Informasi dan } \\
\text { Komunikasi }\end{array}$ & $550.038,78$ & $612.285,62$ & $671.765,20$ & $742.405,21$ & $817.499,25$ & $901.826,53$ \\
\hline $\begin{array}{l}\text { Jasa Keuangan } \\
\text { dan Asuransi }\end{array}$ & $463.984,51$ & $549.659,37$ & $603.705,06$ & $689.122,10$ & $771.752,59$ & $872.618,70$ \\
\hline Real Estat & $15.157,28$ & $17.654,50$ & $20.147,47$ & $23.229,66$ & $26.646,62$ & $30.644,63$ \\
\hline Jasa Perusahaan & $52.560,51$ & $58.321,20$ & $65.254,15$ & $72.708,67$ & $81.183,35$ & $90.551,71$ \\
\hline $\begin{array}{l}\text { Administrasi } \\
\text { Pemerintahan, } \\
\text { Pertahanan dan } \\
\text { Jaminan Sosial }\end{array}$ & $1.236 .543,83$ & $1.301 .947,38$ & $1.395 .127,15$ & $1.481 .947,14$ & $1.581 .089,71$ & $1.683 .173,63$ \\
\hline
\end{tabular}




\begin{tabular}{|l|c|c|c|c|c|c|} 
Jasa Pendidikan & $343.180,10$ & $397.768,77$ & $457.845,28$ & $528.834,39$ & $609.768,31$ & $703.700,84$ \\
\hline $\begin{array}{l}\text { Jasa Kesehatan } \\
\text { dan Kegiatan } \\
\text { Sosial }\end{array}$ & $228.415,85$ & $247.483,53$ & $280.124,29$ & $310.289,27$ & $347.458,03$ & $386.976,48$ \\
\hline Jasa Lainnya & $131.865,17$ & $149.653,12$ & $164.534,18$ & $183.811,99$ & $203.719,11$ & $226.685,13$ \\
\hline & $\mathbf{7 . 0 9 4 . 6 1 5 , 4 9}$ & $\mathbf{7 . 8 7 7 . 3 0 9 , 5 0}$ & $\mathbf{8 . 6 8 7 . 9 7 5 , 5 0}$ & $\mathbf{9 . 6 2 4 . 8 2 9 , 6 3}$ & $\mathbf{1 0 . 6 4 8 . 4 8 8 , 5 4}$ & $\mathbf{1 1 . 7 9 9 . 2 9 8 , 3 8}$ \\
\hline
\end{tabular}

\subsection{Analisis Potensi SektorUnggulan}

Sektor unggulan daerah pada dasarnya adalah sektor tersebut dapat memberikan kontribusi yang besar pada daerah, bukan hanya untuk daerah itu sendiri namun juga untuk memenuhi kebutuhan daerah lain, permasalahan utama yang banyak dialami oleh masyarakat nelayan yang ada di kepulauan adalah ketergantungan pada alam atau musim (Haryono 2005; Hernanto 1989; Kadariah et al. 1999).

Menurut Haryono (2005); Cikitha (2018), kriteria pengelompokan komoditas unggulan perikanan di Kota Ternate didasarkan pada beberapa hal, antara lain : (1) Memiliki nilai ekonomi yang tinggi, (2) Mencukupi kebutuhan sendiri dan mampu mensuplai ke daerah lain, (3) Memiliki pasar yang prospektif dan berdaya saing tinggi, (4) Memiliki potensi untuk ditingkatkan nilai tambahnya dalam mina industri, (5) Dapat dibudidayakan secara luas di wilayah Pulau atau Kota.

Subsektor yang memiliki LQ lebih dari 1 menunjukkan sebagai sektor yang peranannya di Kota Ternate lebih dominan dibandingkan peranannya di kecamatan biasanya diidentifikasikan sebagai sektor/subsektor unggulan. setiap kecamatan belum tersedia, Dalam sektor perikanan dapat diperinci dengan dengan subsektor perikanan tangkap, subsector perikanan olahan dan subsektor perikanan budidaya (Ananimous, 2018).

Secara umum, hasil analisis LQ terhadap PDRB atas harga konstan menurut lapangan usaha di Kota Ternate setelah diperbandingkan dengan sektor-sektor di level Provinsi Maluku Utara menunjukkanbahwa LQ sektor pertanian dan perikanan hanya sebesar 0,16. Sektor pertanian dan perikanan, pertambangan dan penggalian serta industry pengolahan masing memiliki nilai LQ sebesar 0,16, 0,01 dan 0,49.Location Quotient (LQ) PDRB Atas Harga Konstan Menurut Lapangan Usaha di Kota Ternate tahun 2016 dan 2017 dapat dilihat pada Tabel 2. 
Tabel 2. Location Quotient (LQ) PDRB Atas Harga Konstan Menurut Lapangan Usaha di Kota Ternate tahun 2016 dan 2017

\begin{tabular}{|c|c|c|c|c|c|c|}
\hline \multirow{2}{*}{ Sektor } & \multicolumn{2}{|c|}{ PDRB Maluku Utara } & \multicolumn{2}{|c|}{ PDRB Kota Ternate } & \multicolumn{2}{|c|}{$\begin{array}{l}\text { LQ Kota } \\
\text { Ternate }\end{array}$} \\
\hline & 2016 & 2017 & 2016 & 2017 & 2016 & 2017 \\
\hline $\begin{array}{l}\text { Pertanian dan } \\
\text { perikanan }\end{array}$ & $4.943 .914,70$ & $5.100 .386,10$ & $212.810,57$ & $219.761,97$ & 0,16 & 0,16 \\
\hline $\begin{array}{l}\text { Pertambangan } \\
\text { dan Penggalian }\end{array}$ & $2.023 .514,40$ & $2.250 .624,20$ & $3.697,75$ & $4.086,51$ & 0,01 & 0,01 \\
\hline $\begin{array}{l}\text { Industri } \\
\text { Pengolahan }\end{array}$ & $1.260 .294,30$ & $1.665 .236,90$ & $213.039,29$ & $217.952,98$ & 0,63 & 0,49 \\
\hline $\begin{array}{l}\text { Pengadaan listrik } \\
\text { dan gas }\end{array}$ & $23.353,30$ & $25.084,90$ & $9.761,25$ & $10.188,90$ & 1,56 & 1,51 \\
\hline $\begin{array}{l}\text { Pengadaan Air, } \\
\text { Pengelolaan } \\
\text { Sampah, Limbah } \\
\text { dan Daur Ulang }\end{array}$ & $19.640,80$ & $21.037,80$ & $4.780,50$ & $5.160,14$ & 0,91 & 0,91 \\
\hline Konstruksi & $1.436 .727,00$ & $1.555 .160,30$ & $390.561,12$ & $423.212,19$ & 1,02 & 1,01 \\
\hline $\begin{array}{l}\text { Perdagangan } \\
\text { Besar dan Kecil }\end{array}$ & $3.916 .438,70$ & $4.169 .508,20$ & $1.491 .361,82$ & $1.615 .531,56$ & 1,42 & 1,44 \\
\hline $\begin{array}{l}\text { Transportasi dan } \\
\text { Pergudangan }\end{array}$ & $1.249 .703,20$ & $1.349 .823,50$ & $877.991,37$ & $962.333,25$ & 2,63 & 2,66 \\
\hline $\begin{array}{l}\text { Penyediaan } \\
\text { akomodasi dan } \\
\text { Makan }\end{array}$ & $99.128,40$ & $108.760,50$ & $64.360,04$ & $70.949,47$ & 2,43 & 2,43 \\
\hline $\begin{array}{l}\text { Informasi dan } \\
\text { Komunikasi }\end{array}$ & $964.101,20$ & $1.028 .361,50$ & $545.345,88$ & $589.791,16$ & 2,11 & 2,14 \\
\hline $\begin{array}{l}\text { Jasa Keuangan } \\
\text { dan Asuransi }\end{array}$ & $671.498,80$ & $706.959,00$ & $400.158,67$ & $423.112,79$ & 2,23 & 2,23 \\
\hline Real Estat & $25.857,20$ & $27.974,40$ & $13.552,56$ & $14.973,46$ & 1,96 & 2,00 \\
\hline Jasa Perusahaan & $73.733,50$ & $78.632,60$ & $46.181,47$ & $50.412,12$ & 2,34 & 2,39 \\
\hline $\begin{array}{l}\text { Administrasi } \\
\text { Pemerintahan, } \\
\text { Pertahanan dan } \\
\text { Jaminan Sosial } \\
\end{array}$ & $3.453 .590,50$ & $3.645 .937,40$ & $930.913,17$ & $989.113,29$ & 1,01 & 1,01 \\
\hline Jasa Pendidikan & $745.989,20$ & $788.025,60$ & $257.956,62$ & $295.967,16$ & 1,29 & 1,40 \\
\hline $\begin{array}{l}\text { Jasa Kesehatan } \\
\text { dan Kegiatan } \\
\text { Sosial } \\
\end{array}$ & $466.896,10$ & $495.862,50$ & $187.749,11$ & $206.125,42$ & 1,50 & 1,55 \\
\hline Jasa Lainnya & $182.298,40$ & $193.488,90$ & $117.213,24$ & $125.783,43$ & 2,40 & 2,42 \\
\hline Jumlah & $21.556 .679,70$ & $23.210 .864,30$ & $5.767 .434,43$ & $6.224 .455,80$ & 25,61 & 25,78 \\
\hline
\end{tabular}

Sumber Data diolah

\subsection{Subsektor PerikananTangkap}


Berdasarkan potensi sumberdaya ikan di WPP 715, maka potensi sumberdaya ikan di Kota Ternate dapat diestimasi secara kasar dengan pendekatan ratio luas wilayah pengelolaan perikanan (WPP) dengan luas perairannya yakni 0,507\% dari luas perairan WPP 715 atau seluas $5547,55 \mathrm{~km}^{2}$. Dengan pendekatan rasio tersebut, maka perairan Kota Ternate memiliki total potensi sumber daya ikan sebesar 6.300,495 ton/tahun yang terdiri dari ikan pelagis besar, kecil, demersal, kerang-kerangan konsumsi, udang, lobster dan cumi-cumi (Ananimous, 2017).

Potensi tersebut di luar estimasi potensi sumberdaya ikan cakalang dan tuna karena kedua jenis ikan ini tidak dapat dihitung potensi lestarinya. Hal ini dikarenakan kedua jenis ikan tersebut termasuk dalam jenis ikan yang bermigrasi jauh sehingga tidak dapat ditentukan potensinya pada daerah tertentu saja. Dengan mengetahui besaran potensi SDI, sehingga dapat menentukan kebijakan yang sesuai untuk proses pengembangan perikanan ke depan. Konsep optimasi yang digunakan dalam penelitian ini adalah model bioekonomi (Grafton et al. 2010; Sumaila and Hannesson 2010). Potensi SDI dikaji dengan model bioekonomi (Grafton et al. 2010; Sumaila and Hannesson 2010).

Model bio-ekonomi SDI diduga dengan model Gordon-Schaefer Fox, dengan berdasarkan pada model biologi Schaefer-Fox dan model ekonomi Gordon. Model ini disusun dari model parameter biologi, biaya penangkapan dan harga ikan. Hubungan hasil tangkapan dengan upaya penangkapan dilihat dengan menggunakan metode surplus produksi Schaefer-Fox (Sparre and Venema, 1999). Estimasi potensi SDI WPP 715 dan SDI Kota Ternate untuk beberapa jenis ikan laut dapat dilihat pada Tabel3.

Tabel3. Estimasi potensi lestari sumberdaya ikan di Perairan Kota Ternate Tahun 2018

\begin{tabular}{|l|c|c|c|c|}
\hline $\begin{array}{c}\text { Jenis } \\
\begin{array}{c}\text { Sumberdaya } \\
\text { Ikan } \\
\text { (SDI) }\end{array}\end{array}$ & $\begin{array}{c}\text { Potensi SDI } \\
\text { WPP 715 } \\
\text { (ton/thn) }\end{array}$ & $\begin{array}{c}\text { Tingkat } \\
\text { Pemanfaata } \\
\mathbf{n}\end{array}$ & $\begin{array}{c}\text { Estimasi Potensi } \\
\text { SDI (ton/thn) } \\
\text { Kota Ternate } \\
(0,507 \% \text { x Potensi } \\
\text { SDI WPP 715) }\end{array}$ & $\begin{array}{c}\text { JTB (Jumlah } \\
\text { Tangkap yang } \\
\text { Diperbolehkan } \\
\text { ) } \\
\text { (80\% dari } \\
\text { potensi Lestari) }\end{array}$ \\
\hline Pelagis Kecil & $555.982,00$ & 0,88 & $2.819,22$ & $2.255,38$ \\
\hline Pelagis Besar & $31.659,00$ & 0,97 & 160,53 & 128,43 \\
\hline Demersal & $325.080,00$ & 0,22 & $1.648,39$ & $1.318,71$ \\
\hline Karang konsumsi & $310.866,00$ & 0,34 & $1.576,31$ & $1.261,05$ \\
\hline Udang & $6.436,00$ & 0,78 & 32,64 & 26,11 \\
\hline Lobster & 846 & 1,32 & 4,29 & 3,43 \\
\hline Kepiting & 891 & 1,19 & 4,52 & 3,61 \\
\hline Ranjungan & 495 & 0,98 & 2,51 & 41,67 \\
\hline Cumi-cumi & $10.272,00$ & 1,86 & 52,09 & $\mathbf{5 . 0 4 0 , 3 9 6}$ \\
\hline \multicolumn{1}{|c|}{ Jumlah } & $\mathbf{1 . 2 4 2 . 5 2 7 , 0 0}$ & & $\mathbf{6 . 3 0 0 , 4 9 6}$ & \\
\hline
\end{tabular}

Sumber: Diolah dari data Kepmen KP No. 50 Tahun 2017

Keterangan :

*Ikan Pelagis besar $=$ Non Tuna-Cakalang

Tingkat pemanfaatan :

$<0,5 \quad$ : Moderat (upaya penangkapan dapat ditambah);

$0,5<1$ : Fully Eksploited (upaya penangkapan dipertahankan dengan pengawasan yang ketat;

$\geq 1 \quad$ : Over Eksploitasi (Upaya penangkapan harus dikurangi). 
Berdasarkan estimasi potensi lestari perikanan tangkap di atas, maka tingkat pemanfaatan pelagis kecil dan pelagis besar di perairan WPP 715 sudah berada dalam fully ekspolited yang berarti bahwa upaya penangkapan pada jenis ikan tersebut perlu pengawasan yang ketat karena sudah mendekati over ekspolitasi. Tingkat Pemanfaatan Sumberdaya Ikan di WPP715 dapat dilihat pada Gambar 1.

Tingkat Pemanfaatan Sumberdaya Ikan di WPP 715

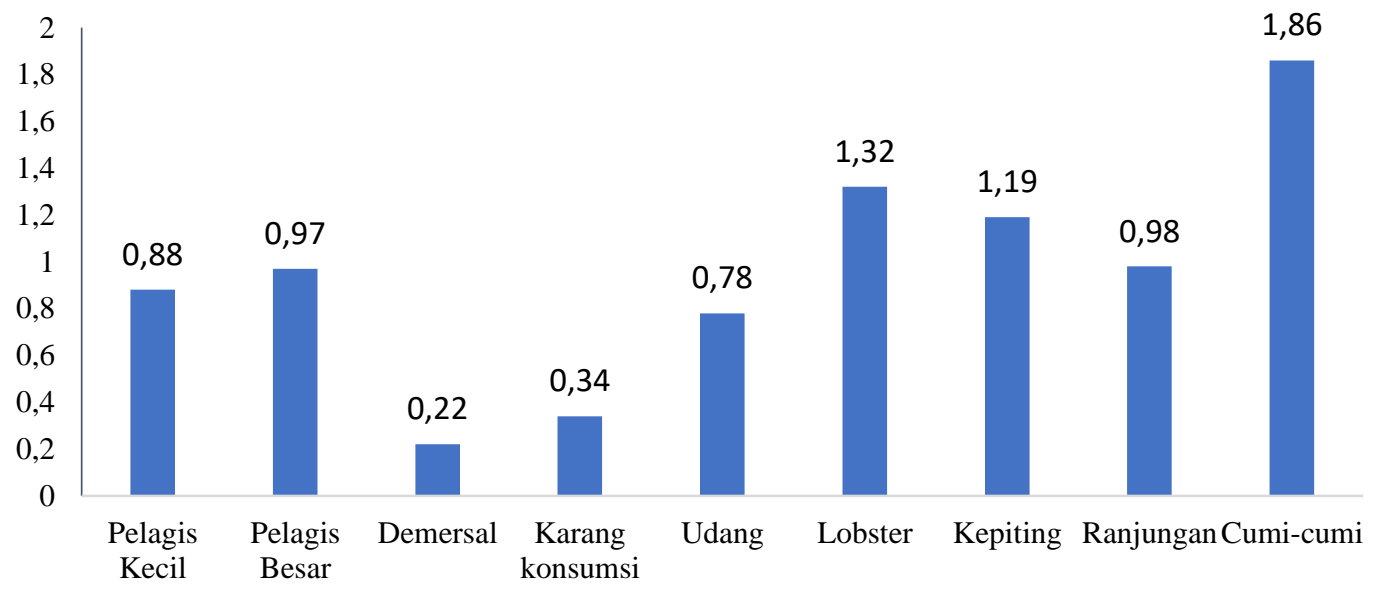

Gambar 1 Tingkat Pemanfaatan Sumberdaya Ikan di WPP715

Sumber : Kepmen-KP No 50 Tahun 2017

Menurut Zulham dkk, (2017) tingkat pemanfaatan ikan pelagis kecil dan ikan pelagis besar di perairan Kota Ternate sudah mengalami over exploited dengan nilai tingkat pemanfaatan 1.05 dan 1,58. Nilai pemanfaatan yang belum over exploited adalah ikan demersal dan ikan karang dengan tingkat pemanfaatan 0,51 dan 0,49. Jenis ikan yang dominan ditangkap dan diproduksi di perairan Ternate dan sekitarnya pada tahun 2017 dan 2018 adalah Cakalang, tuna, tongkol, kembung dan layang. Jumlah yang didaraktkan di PPN Ternate dari jenis-jenis ikan dominan tersebut pada tahun 2017 mencapai 15.979 ton dan 18.694,57 ton pada tahun 2018 .

Selain jenis ikan tersebut, beberapa pelagis kecil yang juga sering ditemui dalam jumlah yang banyak di Kota Ternate antara lain ikan selar. Di Kota Ternate, selain dijadikan sebagai sumber makanan untuk memenuhi kebutuhan protein, ikan pelagis belakangan ini digunakan sebagai ikan umpan dalam perikanan rawai tuna (tuna long line) dan cakalang (huhate), sehingga permintaan pasar terhadap ikan ini tinggi. Inilah yang menjadi salah satu penyebab stok atau populasi ikan pelagis kecil di Kota Ternate semakin hari semakin menurun meskipun ikan pelagis kecil termasuk dalam Sumberdaya yang dapat pulih.Perkembangan Produksi jenis-jenis ikan dominan di Kota Ternate dapat dilihat pada Gambar 2. 
Perkembangan Produksi jenis-jenis ikan dominan di Kota Ternate

Tahun 2016-2018

$14.000,00$

$12.000,00$

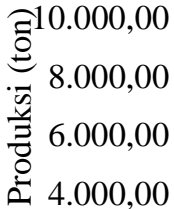

$2.000,00$
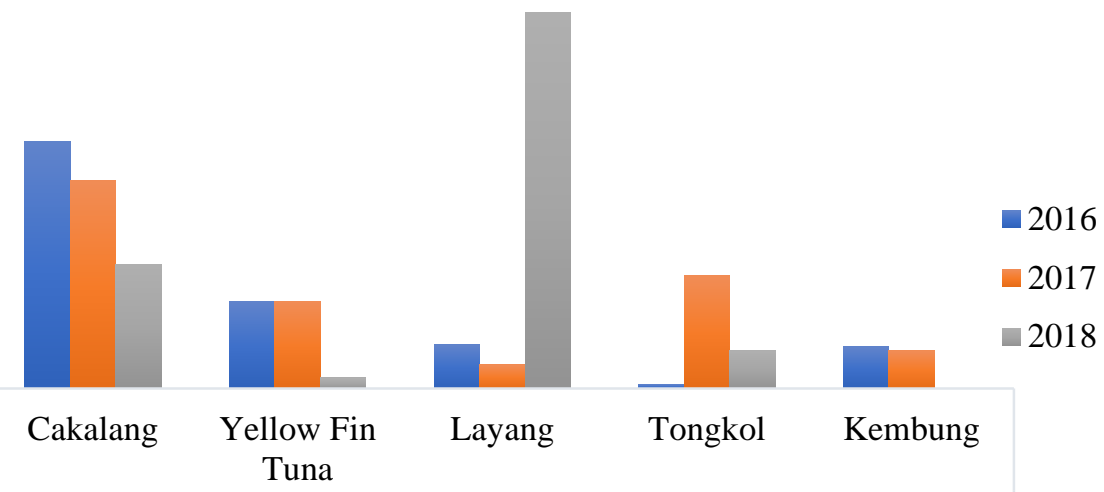

Jenis Ikan

Gambar 2. Perkembangan Produksi jenis-jenis ikan dominan di Kota Ternate. Sumber: Diolah dari data Pusat Riset Perikanan (2017) dan Dinas Kelautan dan Perikanan Kota Ternate (2018).

Jika merujuk pada Kepmen-KP No 50 Tahun 2017 tentang potensi lestari ikan di masingmasing WPP di Indoensia, bahwa jenis ikan yang dapat dihitung potensi lestarinya adalah semua jenis ikan di luar jenis cakalang dan tuna (non cakalang-tuna), maka jumlah ikan yang didaratkan di PPN Ternate pada tahun 2018 yang mencapai 14.719,72 ton (Tabel 3.7) telah melebihi potensi lestari perairan Kota Ternate (6.300,496 ton/tahun). Hal ini memerlukan perhatian terutama bagi pelagis kecil dan pelagis besar yang sudah mencapai over exploitasi, dan ikan karang konsumsi dalam kondisi moderat. Dalam hal ini, pelagis besar tidak termasuk over exploited untuk ikan tuna dan cakalang. Ini merupakan pengecualian karena ikan ini adalah peruaya yang jauh sehingga memungkinkan adanya pengembangan perikanan tangkap ikan tuna dan cakalang, bagi kemajuan dan kesejahteraan masyarakat nelayan dengan melihat kepada faktor kelestariannya.

Hasil perhitungan nilai potensi dan produksi ikan di PPN Ternate telah melebihi potensi lestari perairan Kota ternate, namun belum bisa dijadikan dasar untuk mengklaim bahwa perairan Kota Ternate telah mengalami over fishing karena sebagian ikan yang didaratkan di PPN Ternate tersebut ditangkap di luar wilayah perairan Ternate seperti perairan Bacan, Perairan Halmahera Barat dan sekitarnya. Belum ada data yang riil di PPN ternate mengenai jumlah ikan yang khusus ditangkap di perairan ternate sehingga ke depannya perlu dilakukan pendataan yang lebih valid 
mengenai asal usul ikan (lokasi penangkapan masing-masing ikan yang didaratkan baik di PPN

Ternate, maupun yang didaratkan di pantai-pantai sekitar Ternate (distribusi langsung ke konsumen seperti Sasa, Rua, Tobololo, Sulamadaha, Moti, Batang Dua pantai dan lainnya).Jumlah RTP tangkap di Kota Ternate tahun 2017 sebesar 5.009 RTP, dengan jumlah kelompok nelayan sebesar 44 kelompok. Jumlah RTP terbanyak terdapat di Kecamatan Ternate Utara sebanyak 1.089 RTP. Jumlah RTP tangkap berdasarkan Kecamatan di Kota Ternate Tahun 2017 dapat dilihat pada Tabel 4.

Tabel 4. Jumlah RTP tangkap berdasarkan Kecamatan di Kota Ternate Tahun 2017

\begin{tabular}{|c|c|c|c|c|c|c|}
\hline \multirow{2}{*}{ Kecamatan } & \multirow{2}{*}{ RTP } & \multirow{2}{*}{$\begin{array}{c}\text { Kelompok } \\
\text { Nelayan }\end{array}$} & \multirow{2}{*}{$\begin{array}{c}\text { Kelompok } \\
\text { Nelayan }\end{array}$} & \multicolumn{3}{|c|}{ Jumlah Armada } \\
\hline & & & & \multicolumn{3}{|c|}{2018} \\
\hline Pulau Ternate $*$ & 655 & 3 & 3 & PTM & MT & $\mathbf{K M}$ \\
\hline Moti & 850 & 1 & 1 & 189 & 30 & 28 \\
\hline $\begin{array}{l}\text { Pulau Batang } \\
\text { Dua }\end{array}$ & 533 & 5 & 5 & 264 & 28 & 32 \\
\hline Pulau Hiri & 596 & 1 & 1 & 165 & 25 & 28 \\
\hline $\begin{array}{l}\text { Ternate Barat } \\
* *\end{array}$ & -- & 1 & 1 & 178 & 22 & 38 \\
\hline Ternate Selatan & 777 & 13 & 13 & 0 & 0 & 0 \\
\hline Ternate Tengah & 509 & 7 & 7 & 234 & 51 & 60 \\
\hline Ternate Utara & 1089 & 13 & 13 & 167 & 26 & 23 \\
\hline Jumlah & 5009 & 44 & 44 & 349 & 36 & 113 \\
\hline & & & & 1546 & 218 & 322 \\
\hline
\end{tabular}

Sumber : Dinas Kelautan dan Perikanan Kota Ternate dalam Ternate Dalam Angka 2018

Ket: RTP= Jumlah rumah Tangga Perikanan

PTM = Perahu Tanpa Motor

MT = Motor Tempel

$\mathrm{KM}=$ Kapal Motor

Pengelompokkan jenis armada tangkap yang digunakan oleh nelayan di Kota Ternate, yakni Perahu Tanpa Motor, Armada dengan Motor Tempel dan Armada kapal Motor.Berdasarkan data dari Dinas Kelautan dan Perikanan Kota Ternate, jumlah armada tangkap di Kota Ternate menurun dari 3.243 unit pada tahun 2014 menjadi 3.095 unit pada tahun 2016 dan tersisa 2.086 pada tahun 2017. Komposisi armada perikanan perahu tanpa motor meningkat dari 44,1\% 2014 menjadi 51,6\% pada tahun 2016 dan menjadi 74,11\% pada tahun 2017; armada motor tempel menurun dari 18,1\% pada tahun 2014 menjadi $5,1 \%$ pada tahun 2016 dan turun menjadi 10,45\% pada tahun 2017. Komposisi armada kapal motor meningkat dari 8,2\% (2014) menjadi 10,3\% pada tahun 2016 dan mencapai 15,4\% pada tahun 2017 (Tabel 
3.4.). Perkembangan armada tangkap di Kota Ternate, Tahun 2014-2017 di sajikan pada (Gambar 3.12).

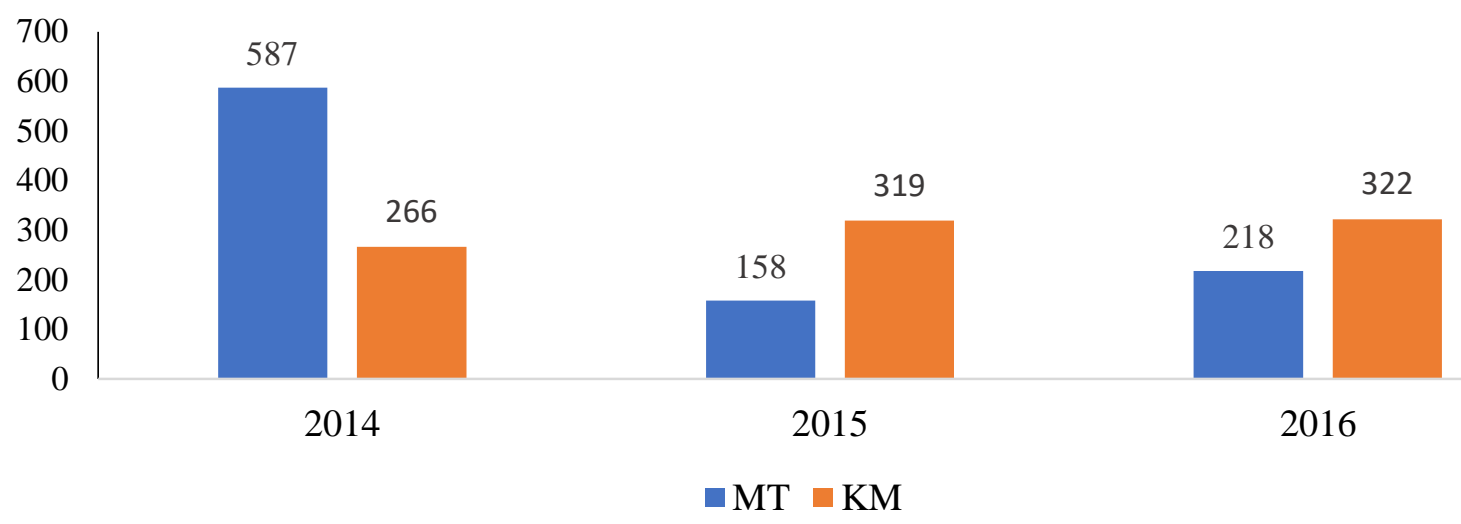

Gambar 3.Perkembangan jumlah armada tangkap dengan motor (unit) di Kota Ternate Tahun 2014-2017

\subsection{Alattangka}

Jenis alat tangkap yang digunakan nelayan di Kota Ternate, ada sekitar 9 jenis alat tangkap yang terdiri dari bagan perahu (boat lift net),jaring insang, pukat cincin/giop (mini purse seine), pancing ulur (hand line), rawai bubu. Untuk alat tangkap perikanan rakyat, pukat cincin, pukat pantai, jarring insang (hanyut dan tetap), bagan perahu, huhate (pole and line), rawai (dasar dan hanyut), pancing tonda (hand line), bubu. Sedangkan untuk perikanan komersial hanya 6 jenis alat tangkap yakni Huhate (pole and line), Pukat cincin (purse sein), Pancing ulur (hand line), jaring insang (gill net), Muroami, dan Bagan perahu (boat lift net). Perkembangan jumlah alat tangkap ikan (unit) di Kota Ternate tahun 2015-2018 dapat dilihat pada Tabel 5.

Tabel 5. Perkembangan jumlah alat tangkap ikan (unit) di Kota Ternate tahun 2015-2018

\begin{tabular}{|c|l|c|c|c|c|}
\hline \multirow{2}{*}{ No } & \multirow{2}{*}{ Alat Tangkap } & \multicolumn{4}{c|}{ Tahun } \\
\cline { 3 - 5 } & & $\mathbf{2 0 1 5}$ & $\mathbf{2 0 1 6}$ & $\mathbf{2 0 1 7}$ & $\mathbf{2 0 1 8}$ \\
\hline 1 & Purse Seine (Pukat Cincin) & $2.704,40$ & $2.159,80$ & $1.879,2$ & $2.215,8$ \\
\hline 2 & Gill Net (Jaring Insang) & 230,6 & 90,7 & 209,0 & 113 \\
\hline 3 & Pole and Line (Huhate) & $3.329,20$ & $2.037,10$ & $3.029,0$ & $1.888,3$ \\
\hline 4 & Muroami & 53,7 & 262,7 & 123,3 & 57 \\
\hline 5 & Hand Line (Pancing Ulur) & 823,2 & 841,5 & $1.481,6$ & $1.001,3$ \\
\hline 6 & Bagan & 20,4 & 11,7 & 133,5 & 25,9 \\
\hline & $\mathbf{7 . 1 6 1 , 5 0}$ & $\mathbf{5 . 4 0 3 , 5 0}$ & $\mathbf{6 . 8 5 5 , 6 0}$ & $\mathbf{5 . 3 0 1 , 3}$ \\
\hline
\end{tabular}

Sumber : Dinas Kelautan dan Perikanan Kota Ternate dalam Ternate Dalam Angka 2018 


\subsection{Nilai Produksi PerikananTangkap}

Nilai produksi merupakan hasil penjualan ikan berdasarkan jumlah hasil tangkapan yang diperoleh oleh nelayan. Total nilai produksi perikanan tangkap Kota Ternate pada tahun 2018 mencapai Rp. 123.590.700.000.Nilai produksi perikanan tangkap ini didasarkan pada pencatatan PPN Ternate yang merupakan gabungan dari nilai produksi beberapa jenis ikan yang dominan didaratkan di Kota Ternate pada tahun 2018 yakni ikan layang, cakalang, tongkol, tuna, lolosi, kurisi, kuwe dan ikan lainnya. Informasi lengkap mengenai nilai produksi dari masing-masing jenis ikan tersebut disajikan pada Tabel 6. Berdasarkan catatan harian dari PPN Ternate, dengan mengambil sampel pada tanggal 20 Oktober 2018, aktivitas pendaratan ikan di PPN Ternate pada hari itu di dominasi oleh ikan layang sebanyak 35 Ton dengan Nilai Rp. 351.120.000 yang melibatkan 15 Kapal perikanan dengan ukuran kapal <10 GT sebanyak 10 unit kapal, 10-30 GT 4 Unit Kapal dan >30 GT 1 Unit Kapal dengan total produksi hasil pendaratan 52,9 Ton dengan Nilai Rp. 686.615.000. Dengan asumsi bahwa produksi harian ikan sepanjang tahun 2018 tidak mengalami perubahan yang signifikan, maka jumlah ikan yang didaratkan di PPN Ternate pada tahun 2018 adalah 19.315,44 ton dengan rincian cakalang tuna sebanyak 4.595,72 ton dan nontuna cakalang sebanyak 14.719,72 ton. Dalam catatan harian PPN ternate tersebut, diketahui bahwa nilai harian dari Ikan yang didaratkan di PPN Ternate tersebut adalah Rp. 686.615.000,atau sebesar Rp. 123.590.700.000,- dalam setahun.Nilai produksi rata-rata harian beberapa jenis ikan yang didaratkan di kota PPN Ternate pada tahun 2018 dapat dilhat pada Tabel 6. Sedangkan perkembangan produksi ikan (ton) menurut jenisnya pada masing-masing jenis usaha perikanan (perikanan komersial dan perikanan rakyat) yang didaratkan di PPN Ternate Tahun 2016-2018 dapat dilihat pada Tabel 7.

Tabel 6. Nilai produksi rata-rata harian beberapa jenis ikan yang didaratkan di kota PPN Ternate pada tahun 2018

\begin{tabular}{|c|c|c|c|}
\hline Jenis Ikan Dominan & $\begin{array}{c}\text { Volume } \\
\text { produksi harian } \\
(\mathbf{k g})\end{array}$ & $\begin{array}{c}\text { Nilai produksi } \\
(\mathbf{R p}) \text { rata-rata } \\
\text { harian }\end{array}$ & $\begin{array}{c}\text { Nilai Produksi } \\
\text { (Rp) perikanan } \\
\text { dalam setahun } \\
* *)\end{array}$ \\
\hline Layang & 35.112 & 351.120 .000 & 63.201 .600 .000 \\
\hline
\end{tabular}




\begin{tabular}{|c|c|c|c|}
\hline Jenis Ikan Dominan & $\begin{array}{c}\text { Volume } \\
\text { produksi harian } \\
(\mathbf{k g})\end{array}$ & $\begin{array}{c}\text { Nilai produksi } \\
(\mathbf{R p )} \text { rata-rata } \\
\text { harian }\end{array}$ & $\begin{array}{c}\text { Nilai Produksi } \\
\text { (Rp) perikanan } \\
\text { dalam setahun } \\
* *)\end{array}$ \\
\hline Cakalang & 11.605 & 220.495 .000 & 39.689 .100 .000 \\
\hline Tongkol & 3.515 & 35.150 .000 & 6.327 .000 .000 \\
\hline Tuna & 986 & 15.755 .000 & 2.835 .900 .000 \\
\hline Lolosi & 241 & 6.025 .000 & 1.084 .500 .000 \\
\hline Kurisi & 221 & 8.840 .000 & 1.591 .200 .000 \\
\hline Kuwe & 214 & 9.630 .000 & 1.733 .400 .000 \\
\hline Lainnya & 1.025 & 39.600 .000 & 7.128 .000 .000 \\
\hline Total & $\mathbf{5 2 . 9 1 9}$ & $\mathbf{6 8 6 . 6 1 5 . 0 0 0}$ & $\mathbf{1 2 3 . 5 9 0 . 7 0 0 . 0 0 0}$ \\
\hline
\end{tabular}

Sumber. Pelabuhan Perikanan Nusantara, Dirjen Perikanan Tangkap 2018. Diolah

Keterangan :

**) nilai produksi tersebut dicapai jika diasumsikan selama tahun 2018, rata-rata nelayan dapat melaut dan mendaratkan ikan dalam sebulan sebanyak 15 kali selama 12 bulan.

Tabel 7. Perkembangan Produksi Ikan (ton) menurut jenisnya Pada masing-masing jenis usaha perikanan (perikanan komersial dan perikanan rakyat) yang didaratkan di PPN Ternate Tahun 2016-2018.

\begin{tabular}{|l|c|c|c|c|c|}
\hline \multirow{2}{*}{ Jenis Ikan } & \multicolumn{3}{|c|}{$\mathbf{2 0 1 6} *$} & \multirow{2}{*}{$\mathbf{2 0 1 7} * *$} & \multirow{2}{*}{$\mathbf{2 0 1 8}$} \\
\cline { 2 - 5 } & Komersil & $\begin{array}{c}\text { Perik. } \\
\text { Rakyat }\end{array}$ & Total & \\
\hline Cakalang & $2.008,03$ & $6.425,14$ & $8.433,17$ & $7.083,45$ & $4.235,825$ \\
\hline Yellow Fin Tuna & 284,79 & $2.697,85$ & $2.982,64$ & $2.975,44$ & 359,89 \\
\hline Layang & $1.491,54$ & & $1.491,54$ & 802,95 & $12.815,88$ \\
\hline Ekor Kuning & 241,35 & 887,45 & $1.128,80$ & & \\
\hline Kembung & 246,18 & $1.171,43$ & $1.417,61$ & $1.280,62$ & \\
\hline Tenggiri & 24,14 & 212,99 & 237,12 & 138,11 & \\
\hline Lemuru/Tembang & 24,14 & 532,47 & 556,61 & & \\
\hline Lencam & 125,50 & 390,48 & 515,98 & & \\
\hline Kakap & 115,85 & 656,71 & 772,56 & 726,9 & \\
\hline Kerapu & 11,02 & 603,47 & 714,49 & & \\
\hline Kuwe & 125,50 & & 125,50 & 403,5 & 78,11 \\
\hline Tongkol & & 141,99 & 141,99 & $3.836,54$ & $1.282,98$ \\
\hline lainnya & 28,96 & & 28,96 & & 374,13 \\
\hline Peperek & & 425,98 & 425,98 & 463,84 & \\
\hline Biji Nangka & 390,48 & 390,48 & & \\
\hline Gerot-gerot & 390,48 & 390,48 & & \\
\hline Bambangan & 692,21 & 692,21 & & \\
\hline Manyung & & 221,86 & 221,86 & & \\
\hline Beloso & & 319,48 & 319,48 & 308,28 & \\
\hline
\end{tabular}




\begin{tabular}{|c|c|c|c|c|c|}
\hline \multirow[b]{2}{*}{ Jenis Ikan } & \multicolumn{3}{|c|}{$2016 *$} & \multirow[b]{2}{*}{$2017 * *$} & \multirow[b]{2}{*}{2018} \\
\hline & Komersil & $\begin{array}{c}\text { Perik. } \\
\text { Rakyat }\end{array}$ & Total & & \\
\hline Bawal Putih & & 283,98 & 283,98 & 671,06 & \\
\hline Kurisi & & 221,86 & 221,86 & & 80,67 \\
\hline Cucut & & 328,36 & 328,36 & 299,37 & \\
\hline Pari & & 266,24 & 266,24 & 189,09 & \\
\hline Japuh & & 239,61 & 239,61 & & \\
\hline Swangi & & 248,49 & 248,49 & & \\
\hline Selar & & & & 1201,35 & 89,97 \\
\hline Tetengkek & & & & 113,67 & \\
\hline Terubuk & & & - & 308,07 & \\
\hline Julung & & & & 667,25 & \\
\hline Teri & & & & 1537,26 & \\
\hline Total Produksi & 4827 & 17.749 & 22.576 & 23.007 & 19.315.44 \\
\hline \multicolumn{3}{|c|}{ Cakalang + Tuna $=$} & $12.544,61$ & $10.058,89$ & 4.595 .72 \\
\hline \multicolumn{3}{|c|}{ Non Cakalang + Tuna $=$} & $10.031,39$ & $12.947,86$ & 14.719 .72 \\
\hline
\end{tabular}

Sumber : Pusat Riset Perikanan, 2017 dan Dinas Kelautan dan Perikanan Kota Ternate

*) :Pusat Riset Perikanan, 2017

**) :Dinas Kelautan dan Perikanan Kota Ternate dalam Ternate dalam Angka 2018

Cakalang, tuna, tongkol, kembung dan layang merupakan komoditas perikanan tangkap penting dari Kota Ternate pada tahun 2017 di mana total produksi kelima jenis ikan tersebut mencapai 15.979 ton pada tahun 2017 dan pada tahun 2018 mencapai 18.694,57 ton. Menurut data dari Zulham $d k k$ (2017) Ikan Tuna umumnya dikirim dalam bentuk beku ke Bitung, Makasar dan Jakarta. Ikan Layang sekitar 15\% dijual segar untuk konsumsi masyarakat di Pasar Bastiong dan sisanya dikirim ke Makasar dan Surabaya dalam bentuk beku. Cakalang pasarnya cukup luas. Di Kota Ternate pasar Cakalang adalah untuk konsumsi lokal (10\%) dan bahan baku ikan asap (15\%). Ikan asap diproduksi oleh industri rumah tangga di Pulau Maitara dan Kota Ternate dan produksinya dikirim sampai ke Bitung dan Manado.Upaya pengembangan sektor perikanan sebagai salah satu lapangan usaha yang potensial mendatangkan pendapatan masyarakatnya memerlukan teknologi dan sarana prasarana.

Menurut Kusumastanto (2003), teknologi untuk nelayan hendaknya difokuskan pada upaya penciptaan kemandirian masyarakat melalui penguasaan, pengembangan dan penerapan teknologi untuk optimalisasi pengelolaan SDI, termasuk rehabilitasi habitat ikan, seperti bahan dan peralatan yang produktif, efisien, dan berwawasan lingkungan bagi pengembangan perikanan rakyat. Penggunaan jenis alat tangkap yang beragam dan berubah-ubah sesuai musim 
ikan, menyebabkan perubahan pada daerah perairan yang menjadi lokasi daerah penangkapan ikan (Dalzell et al. 1996; Auster et al. 1997; Jennings and Kaiser 1998).

\subsection{Sub Sektor Perikanan Tangkap}

Berdasarkan jenis ikan yang didaratkan di PPN Ternate, maka ikan tuna, tongkol dan cakalang merupakan komoditas perikanan yang paling dominan di daratkan di PPN Ternate selain ikan kembung, layang, tembang dan tude dari jenis pelagis kecil. Khusus untuk jenis ikan caklang dan tuna, ikan ini merupakan komoditas yang berbasis pada upaya penangkapan artinya jumlah produksinya tergantung dari upaya tangkap yang dilakukan sehingga ketersediaannya untuk level industry tidak tergantung dari potensi lestari suatu perariran tapi harus dengan upaya tangkap yang optimum. Urutan jenis ikan yang dominan di kota Ternate (Tabel 8).

Tabel 8. Urutan jenis ikan dominan menurut jumlah hasil tangkapan yang didaratkan di Ternate dalam kurun waktu 2016-2018.

\begin{tabular}{|c|c|c|}
\hline No & Jenis Ikan & Jumlah Produksi (ton) \\
\hline 1 & Cakalang & $19.752,45$ \\
\hline 2 & Layang & $15.110,37$ \\
\hline 3 & Yellow Fin Tuna & $6.317,97$ \\
\hline 4 & Tongkol & $5.261,51$ \\
\hline 5 & Kembung & $2.698,23$ \\
\hline 6 & Teri & $1.537,26$ \\
\hline 7 & Kakap & $1.499,46$ \\
\hline 8 & Selar & $1.289,32$ \\
\hline 9 & Ekor Kuning & $1.128,80$ \\
\hline 10 & Bawal Putih & 955,04 \\
\hline 11 & Peperek & 889,82 \\
\hline 12 & Kerapu & 714,49 \\
\hline 13 & Bambangan & 692,21 \\
\hline 14 & Julung & 667,25 \\
\hline 15 & Beloso & 627,76 \\
\hline 16 & Cucut & 627,73 \\
\hline 17 & Kuwe & 607,11 \\
\hline 18 & Lemuru/Tembang & 556,61 \\
\hline 19 & Lencam & 515,98 \\
\hline
\end{tabular}

Data diolah 


\subsection{Sub Sektor Perikanan Budidaya}

Berdasarkan data produksi yang diperoleh dari data BPS (Ternate dalam Angka, 2018), komoditas unggulan subsector perikanan budidaya Kota Ternate terdiri dari ikan nila, mas dan lele yang tersebar di Kecamatan Ternate Selatan (Ngade), Rumput laut yang tersebar di Kecamatan Moti dan Ternate Selatan dan Pulau Ternate, Kecamatan yang paling banyak menyumbang komditas budidaya perikanan adalah kecamatan ternate selatan dengan jumlah komoditas sebanyak 3 jenis yakni ikan Nila, Mas dan Rumput laut.Secara keseluruhan, komoditas unggulan sektor perikanan di Kota Ternate (Tabel 3.20).

Berdasarkan tabel diatas, maka kecamatan yang paling banyak memiliki komoditas unggulan pada sub sektor perikanan tangkap dan budidaya adalah Kecamatan Moti, Ternate Tengah, Ternate Selatan dan Ternate Utara.

\section{Sub Sektor Pengolahan Perikanan}

Usaha olahan ikan yang ada di Kota Ternate tersebar di Kecamatan Ternate Tengah, Ternate Utara, Pulau Ternate, Hiri dan Moti. Berdasarkan jenis olahan dan skala usaha, maka unit pengolahan dan pemasaran ikan olahan cakalang asap/fufu skala mikro menjadi jenis olahan yang paling dominan di Kota Ternate dengan jumlah 40 unit usaha. Selain unit usaha skala mikro, unit olahan ikan skala rumah tangga juga banyak menghasilkan ikan asap, abon ikan, dan nugget ikan di Kota Ternate.

Selain jenis-jenis olahan di atas, beberapa produk olahan juga sering dijumpai meskipun dalam jumlah yang tidak terlalu banyak misalnya ikan presto dan bakso ikan.Pengelolaan dan pengembangan potensi SDI unggulan perlu dilakukan secara optimal, sehingga diharapkan dapat menggerakkan ekonomi wilayah dan mengurangi kesenjangan antar wilayah. Pendekatan yang digunakan untuk menduga potensi SDI di suatu wilayah, sebagaimana diungkapkan oleh Supardan et al. (2006), Tinungki (2005) dan Murdiyanto (2004), menggunakan data dan informasi hasil tangkapan per upaya penangkapan minimal lima tahun terkahir.

Kriteria kelayakan dalam hal ini mengacu pada nilai standar sesuai kriteria yang dikemukakan oleh Hernanto (1989) dan Kadariah et al. (1999). Namun pengusahaan setiap jenis alat tangkap harus disesuaikan dengan peraturan yang berlaku dan sesuai 
dengan prinsip konservasi. Komoditas unggulan sektor perikananmemegang peranan sangat penting dalam menunjang ketahanan pangan dan kesejahteraan masyarakat di pulau-pulau kecil termasuk Kota Ternate di sektor perikanan Kota Ternate, komoditas unggulan di dominasi oleh ikan segar dari perikanan tangkap dan ikan olahan. Penyebaran komoditas dominan dan komoditas unggulan perikanan Kota Ternate Tabel 9.

Tabel 9. Penyebaran komoditas dominan dan komoditas unggulan perikanan Kota Ternate

\begin{tabular}{|c|c|c|c|}
\hline Kecamatan & Tangkap & Budidaya & Pengolahan \\
\hline Pulau Ternate * & $\begin{array}{l}\text { cakalang, tuna, tongkol, } \\
\text { ekor kuning, kerapu }\end{array}$ & rumput laut & \\
\hline Moti & $\begin{array}{l}\text { tongkol, tuna, sorihi, } \\
\text { kerapu, }\end{array}$ & rumput laut & ikan fufu \\
\hline Pulau Batang Dua & $\begin{array}{l}\text { tongkol, tuna, sorihi, } \\
\text { kerapu, }\end{array}$ & & \\
\hline Pulau Hiri & $\begin{array}{l}\text { cakalang, tuna, kerapu, } \\
\text { tongkol, lobster, laying, } \\
\text { sorihi }\end{array}$ & & ikan fufu \\
\hline Ternate Barat ** & & & ikan fufu, \\
\hline Ternate Selatan & $\begin{array}{l}\text { cakalang, tuna, tongkol, } \\
\text { layang, sorihi }\end{array}$ & Nila, Mas & \\
\hline Ternate Tengah & $\begin{array}{l}\text { Cakalang, tuna, tongkol, } \\
\text { ekor kuning, sorihi, } \\
\text { layang }\end{array}$ & & $\begin{array}{l}\text { ikan fufu, abon } \\
\text { ikan, presto, kecap } \\
\text { ikan, sambal ikan, } \\
\text { krupuk ikan }\end{array}$ \\
\hline Ternate Utara & $\begin{array}{l}\text { cakalang, tuna, tongkol, } \\
\text { layang, sorihi, tude }\end{array}$ & & \\
\hline
\end{tabular}

\section{Kesimpulan}

Hasil analisis Location Quotient (LQ) PDRB Atas Harga Konstan menurut Lapangan Usaha di Kota Ternate tahun 2016 dan 2017, sector pertanian dan perikanan berada pada posisi no 1, dengan nilai 0,16. Komoditas unggulan perikanan tangkap Kota Ternate adalah ikan Cakalang. Potensi SDI karang sebesar 6.300,495 ton/tahun dan jumlah tangkapan yang diperbolehkan adalah 5.040,396 ton/tahun. Teknologi penangkapan ikan yang ideal untuk dikembangkan di adalah alat tangkap Purse Seine (Pukat Cincin) dan aramada yang dominan adalah perahu tanpa motor (PTM) 1546 unit. Tingkat kelayakan usaha dari jenis-jenis alat tangkap tepat guna masih bernilai positif dan layak untuk terus diusahakan. 


\section{DAFTAR PUSTAKA}

Agus. A, 2018. Pengelolaan dan Penggunaan Sumberdaya Kelautan/Perikanan Studi Kasus Kota Ternate, Maluku Utara. Jurnal Torani. Vol. 1 (2) June 2018: 81-92. Unhas. Makassar. Ardiwijaya RL, Kartawijaya T, Herdiana Y, 2007. Laporan Teknis - Monitoring Ekologi Taman Nasional Karimunjawa, Monitoring Fase 2. Bogor: Wildlife Conservation Society Marine Program Indonesia. $45 \mathrm{hlm}$.

Auster P, Malatesta R, and Donaldson C, 1997. Distributional responses to small-scale habitat variability by early juvenile silver hake, Merluccius bilinearis. Jurnal Environmental Biology of Fishes (50): 195-200.

Adinugroho G, 2016. Potensi Sub-Sektor Perikanan Untuk Pengembangan Ekonomi di bagian Selatan Gunung Kidul. J. Sosek KP Vol. 11 No. 173-183.

Ananimous, 2017. KEPMEN-KP RI. 2017. Keputusan Menteri Kelautan dan Perikanan Republik Indonesia Nomor 50/Kepmen-KP/2017 Tentang Estimasi Potensi Jumlah Tangkapan yang Diperbolehkan dan Tingkat Pemanfaatan Sumberdaya Ikan di Wilayah Pengelolaan Perikanan Negara Republik Indonesia. KKP-RI Jakarta.

Ananimous. 2013. KEMEN-KP RI 2013. Keputusanmenteri Kelautan Dan Perikanan Republik Indonesia Nomor 7/kepmen KP/2013 tentang Peta Jalan (Road Map) Industrialisasi Kelautan dan Perikanan. Jakarta.

Ananimous. 2016. Dokumen Pemerintah Daerah. 2016. Rencana Pembangunan Jangka Menengah Kota Ternate 2016-2021. Ternate.

Ananimous. 2011. Pusat Penelitian dan Pengembangan Sumberdaya Laut dan Pesisir. 2011. Roadmap Litbang SD Laut dan Pesisir Mendukung Fokus Pembangunan Kelautan dan Perikanan 2010-2014. Badan Litbang KP, KKP. Jakarta.

Ananimous. 2015. Masterplan Perikanan Budidaya. Pengembangan Kawasan dan Komoditas Unggulan Perikanan Daerah. DKP. MU.

Ananimous. 2012. Pembangunan Daerah Dalam Angka. Jakarta. Badan Perencanaan Pembangunan Nasional. Bapenas-RI.

Ananimous, 2018. Ternate Dalam Angka 2018. Badan Badan Pusat Statistik Kota Ternate. BPS.

Budiharsono S, 2005. Teknik Analisis Pembangunan Wilayah Pesisir dan Lautan. Jakarta: PT Pradnya Paramita. 116 hlm.

Cikitha P, A. A. H. Suryana, Zuzy Anna dan Atikah Nurhayati Universitas Padjadjaran, 2018.Analisi Peran Sektor perikanan Terhadap Pembangunan Wilayah Kab. Kuningan Jawa Barat. Jurnal Perikanan dan Kelautan Vol. IX No. 1 (1-8).

Dalzell P, Adams T, and Polunin N, 1996. Coastal fisheries in the Pacific Islands. Oceanography and Marine Biology Annual Review (34): 395-531.

Grafton RQ, Kompas T, Chu L, and Che N. 2010. Maximum economic yield. The Australian Journal of Agricultural and Resources Economics (54): 273-280.

Haluan J dan Nurani TW, 1988. Penerapan Metode Skoring dalam pemilihan Teknologi Penangkapan Ikan yang Sesuai untuk dikembangkan di Suatu Wilayah Perairan. Bulletin PSP (2): 3-16.

Haryono TJS, 2005. Strategi Kelangsungan Hidup Nelayan: Studi tentang diversifikasi pekerjaan keluarga nelayan sebagai salah satu strategi dalam mempertahankan kelangsungan hidup. Berkala Ilmiah Kependudukan (7): 119-128.

Hendayana R, 2003. Aplikasi Metode Location Quotient (LQ) dalam Penentuan Komoditas Unggulan Nasional. Informatika Pertanian (1) : 658-675. 
Hernanto F, 1989. Ilmu Usaha Tani. Jakarta: Penebar Swadaya. 304 hlm.

Irnawati R, Domu Simbolon, Budy Wiryawan, Bambang Murdiyanto, Tri Wiji Nurani. 2010. Analisi Komoditas Unggulan Perikanan tangkap di Taman Nasiolanl Karimumjawa. Jurnal Saintek Perikanan Vol.7. no.1, 2011: 1 - 9

Jennings S, and Kaiser M. 1998. The effects of fishing on marine ecosystems. Advances in Marine Biology (34): 201-352.

Kadariah, L. Karlina, dan C. Gray. 2002. Evaluasi Proyek : Analisa Ekonomis. Edisi 2. Jakarta: Lembaga Penerbit Fakultas Ekonomi Universitas Indonesia. $184 \mathrm{hlm}$.

Kusumastanto T, 2003. Ocean Policy dalam Membangun Negeri Bahari di Era Otonomi Daerah. Jakarta: PT Gramedia Pustaka Utama. $160 \mathrm{hlm.}$

Marimin, 2004. Teknik dan Aplikasi Pengambilan Keputusan Kriteria Majemuk. Bogor: IPB Press dengan Program Pascasarjana IPB. 197 hlm.

Monintja D, 2000. Beberapa teknik pilihan untuk memanfaatkan sumberdaya hayati laut di Indonesia. Buletin PSP (1): 14-25.

Murdiyanto B, 2004. Pengelolaan Sumber Daya Perikanan Pantai. Jakarta: COFISH Project. $200 \mathrm{hlm}$.

Sumaila UR and Hannesson R. 2010. Maximum economic yield in crisis.J. Fish And Fisheries (11): 461-465.

Sparre P. \& Venema S.C, 1999. Introduction to tropical fish stock assessment. Part I - Manual. FAO Fisheries Technical Paper. $376 \mathrm{hlm}$.

Supardan A, Haluan J, Manuwoto, Soemokaryo S, 2006. Maximum Sustainable Yield (MSY) dan Aplikasinya pada Kebijakan Pemanfaatan Sumber Daya Ikan di Teluk Lasongko Kabupaten Buton. Buletin PSP 15:35-49.

Tinungki GM, 2005. Evaluasi Model Produksi Surplus Dalam menduga hasil tangkapan maksimum lestari untuk menunjang kebijakan pengelolaan perikanan lemuru di selat bali [disertasi]. Bogor: IPB. $196 \mathrm{hlm}$

Zulham, A., Subaryono, Thomas Ralp, 2017. Rekomendasi Pengembangan Perikanan Tangkap Di Ternate Dan Sekitarnya. Pusat Riset Perikanan. Badan Riset dan Sumber Daya Manusia Kelautan dan Perikanan. PT. Rajagrafindo Persada. Depok. 